\title{
GAMBARAN FUNGSI GINJAL PADA ANAK DENGAN TERAPI LEUKEMIA LIMFOBLASTIK AKUT DI PUSAT KANKER ANAK ESTELLA RSUP PROF DR RD KANDOU
}

\author{
Kartini W. Adam \\ Adrian Umboh \\ Stefanus Gunawan
${ }^{1}$ Kandidat Skripsi Fakultas Kedokteran Universitas Sam Ratulangi Manado
${ }^{2}$ Bagian Ilmu Kesehatan Anak Fakultas Kedokteran Universitas Sam Ratulangi Manado
Email: kartiniadam52@yahoo.co.id

\begin{abstract}
Leukemia is a neoplastic disease which is characterized with differentiation and proliferation of hematopoietic cells. Chemotherapy is one of the main therapy for cancer until the remission. Metabolites of chemotherapy may damage the kidney cells, ureter, and bladder which is marked with a decrease of kidney functions. This study aimed to obtain the kidney functions of pediatric patients with acute lymphoblastic leukemia (ALL) who got chemotherapy. This was a retrospective-cohort study by collecting the medical records of pediatric patients with ALL in Pediatric Cancer Center Estella of Hospital of Prof. DR. R.D Kandou period January 2010-August 2014, and then analyzed their Glomerulus Filtration Rate (GFR) using Mann-Whitney test on the induction phase and unpaired T-test on the consolidation phase. There were 42 cases in this study. The result showed no significant difference $(P>0.05)$ between the LFG induction and consolidation phase. Conclusion: There was not a significant different betwen renal function of children aged 2-12 years of high risk groups and of standard risk groups who got chemotherapy in induction phase and consolidation phase.
\end{abstract}

Keywords: glomerulus filtration rate, acute lymphoblastic leukemia, chemotherapy

\begin{abstract}
Abstrak: Leukemia adalah penyakit neoplastik yang ditandai dengan diferensiasi dan proliferasi sel hematopoietik. Kemoterapi merupakan pengobatan utama kanker sampai ke tahap remisi. Metabolit obat kemoterapi dapat merusak sel-sel ginjal, ureter, dan kandung kemih ditandai dengan penurunan fungsi ginjal. Penelitian ini bertujuan untuk mengetahui fungsi ginjal pada anak dengan leukemia limfoblastik akut (LLA) yang menjalani kemoterapi. Jenis penelitian yang digunakan adalah kohort retrospektif, dengan cara mengumpulkan rekan medik pasien anak dengan LLA di Pusat Kanker Anak Estella RSUP Prof. DR. R.D Kandou periode Januari 2010-Agustus 2014, lalu menganalisis LFG dengan menggunakan Uji Mannwhitney pada fase induksi dan Uji T tidak berpasangan pada fase konsolidasi. Terdapat 42 kasus dalam penelitian ini. Hasil penelitian memperlihatkan tidak terdapat perbedaan bermakna $(P>0,05)$ antara LFG fase induksi dan konsolidasi. Simpulan: Tidak terdapat perbedaan bermakna antara fungsi ginjal anak usia 2-12 tahun pada kelompok high risk (risiko tinggi) dan kelompok standard risk (risiko standar) setelah menjalani kemoterapi fase induksi dan fase konsolidasi.
\end{abstract}

Kata kunci: laju filtrasi glomerulus, leukemia limfoblastik akut, kemoterapi

Leukemia akut adalah penyakit neoplastik yang ditandai dengan diferensiasi dan proliferasi sel hematopoietik, sehingga menyebabkan penekanan dan penggantian unsur sumsum tulang yang normal. ${ }^{1,2}$ Leukemia terjadi pada semua umur, 
insidens terbesar terjadi pada usia 2-5 tahun dengan rata-rata 4-4,5 kasus/tahun/100.000 anak di bawah umur 15 tahun. Beberapa penelitian melaporkan bahwa jumlah pasien laki-laki lebih besar dari pada perempuan, dan terutama terjadi setelah usia pertama kehidupan. Faktor lingkungan dan genetik memegang peranan penting terjadinya LLA. ${ }^{1,3,4}$

Kemoterapi merupakan pengobatan utama kanker sampai ke tahap remisi pada pasien leukemia. Angka kesembuhan leukemia dengan menggunakan kemoterapi mencapai 80\%. Kemoterapi mempunyai tiga fase berdasarkan kelompok risiko yaitu fase induksi, fase konsolidasi dan fase pemeliharaan. ${ }^{3,4}$ Pada penelitian yang dilakukan oleh The Renal Insufficiency and Anticancer Medication Study menunjukkan insufisiensi ginjal sering ditemukan pada pasien terapi kanker, sehingga penyesuaian dosis obat seringkali diperlukan. ${ }^{3-6}$ Ginjal berfungsi mengeluarkan metabolit obat kemoterapi dari dalam tubuh, metabolit obat kemoterapi tersebut dapat merusak sel-sel ginjal, ureter, dan kandung kemih. ${ }^{6}$

Potensi kerusakan ginjal berbeda-beda sesuai dengan jenis obat kemoterapi yang digunakan. Kerusakan ginjal akibat penggunaan obat kemoterapi dapat bersifat ringan sampai berat, bahkan dapat menyebabkan gagal ginjal. Oleh sebab itu, diperlukan pemeriksaan fungsi ginjal sebelum kemoterapi dan selama proses kemoterapi berlangsung untuk memastikan tidak terdapat penyakit ginjal sebelumnya dan melihat pengaruh obat kemoterapi pada ginjal anak. ${ }^{6,7}$

Berdasarkan latar belakang tersebut maka peneliti ingin mengidentifikasi fungsi ginjal pada anak leukemia limfoblastik akut yang menjalani kemoterapi di Pusat Kanker Anak Estella RSUP Prof. DR. R.D Kandou dengan menghitung LFG.

\section{METODE PENELITIAN}

Jenis penelitian yang digunakan adalah kohort retrospektif, dengan menganalisis LFG. Data diambil dari rekam medis pasien anak dengan LLA di Pusat Pengobatan Kanker Ruang Estella Bagian Ilmu
Kesehatan Anak RSUP Prof. DR. R.D Kandou yang dilaksanakan pada bulan Oktober sampai November 2014.

Sampel pada penelitian ini yaitu pasien anak dengan Leukemia Limfoblastik Akut yang menjalani pengobatan di Bangsal Estella RSUP Prof. DR. R.D Kandou periode Januari 2010-Agustus 2014 yang memenuhi kriteria inklusi yaitu pasien anak LLA yang di rawat lima tahun terakhir, telah menjalani kemoterapi fase induksi dan fase konsolidasi, dirawat di Pusat Pengobatan Kanker Ruang Estella, telah melakukan pemeriksaan laboratorium, pemeriksaan penunjang, dan medical record yang lengkap.

Variabel terikat yaitu laju filtrasi glomerulus, sedangkan variabel bebas dalam penelitian yaitu risiko tinggi LLA dan risiko standard LLA. Risiko tinggi yaitu pasien yang berusia $<1$ atau $>10$ tahun, jumlah leukosit $>50.000 /$ uL atau terjadi penyebaran sel leukemia ke mediastinum, cairan otak atau testis. Kemudian risiko standard LLA yaitu yang tidak terdapat salah satu tanda yang ada pada risiko tinggi LLA. Penilaian fungsi ginjal didasarkan pada kemampuan ekskresi ginjal yang dinyatakan menurut kriteria pRIFLE yaitu stadium risk LFG menurun sampai $25 \%$ dari normal, stadium injury LFG menurun sampai 50\%, dan stadium failure LFG menurun sampai $75 \%$.

\section{HASIL PENELITIAN}

Deskripsi karakteristik sampel penelitian berdasarkan usia dapat dilihat pada Tabel 1.

Tabel 1. Distribusi frekuensi karakteristik sampel berdasarkan usia

\begin{tabular}{ccc}
\hline Usia & Frekuensi & Persentase (\%) \\
\hline$<2$ Tahun & 2 & 4,8 \\
2-12 Tahun & 36 & 85,7 \\
13-21 Tahun & 4 & 9,5 \\
\hline Total & 42 & 100,0
\end{tabular}


Tabel 1 menunjukkan bahwa kelompok terbanyak terdapat pada usia 2-12 tahun yaitu sebanyak $85,7 \%$ diikuti usia $13-21$ tahun sebanyak $9,5 \%$ dan terendah pada usia $<2$ tahun sebanyak 4,8\%.

Tabel 2. Distribusi frekuensi karakteristik sampel berdasarkan jenis kelamin

\begin{tabular}{ccc}
\hline Jenis kelamin & Frekuensi & $\begin{array}{c}\text { Persentase } \\
(\%)\end{array}$ \\
\hline Laki-laki & 21 & 50,0 \\
Perempuan & 21 & 50,0 \\
\hline Total & 42 & 100,0
\end{tabular}

Tabel 2 menunjukkan bahwa sampel dengan jenis kelamin laki-laki jumlahnya sama dengan jumlah sampel berjenis kelamin perempuan dengan persentase lakilaki 50,0\% dan perempuan 50,0\%.

Tabel 3. Distribusi frekuensi karakteristik sampel berdasarkan risiko LLA

\begin{tabular}{ccc}
\hline Risiko LLA & Frekuensi & $\begin{array}{c}\text { Persentase } \\
\text { (\%) }\end{array}$ \\
\hline Standard risk & 17 & 40,5 \\
High risk & 25 & 59,5 \\
\hline Total & 42 & 100,0
\end{tabular}

Tabel 3 menunjukkan bahwa sampel dengan high risk LLA lebih banyak daripada standard risk LLA. Persentase high risk LLA yaitu 59,5\% dan standard risk LLA yaitu 40,5\%.

Tabel 4. Perbandingan LFG pada high risk LLA dan standard risk LLA

\begin{tabular}{lcccc}
\multicolumn{1}{c}{ Fase } & $\begin{array}{c}\text { Mean } \\
\text { LFG }\end{array}$ & $\begin{array}{c}\text { Median } \\
\text { LFG }\end{array}$ & SD & Nilai p \\
\hline Induksi & & & & \\
SR LLA & 198,5 & 170,5 & 77,9 & $0,672 *$ \\
HR LLA & 179,9 & 173,2 & 67,3 & \\
& & & & \\
Konsolidasi & & & & \\
SR LLA & 199,5 & 201,7 & 67,4 & $0,460 * *$ \\
HR LLA & 184,4 & 176,0 & 62,0 & \\
& & & & \\
*berdasarkan hasil uji Mann-whitney & & \\
** berdasarkan hasil uji T tidak berpasangan &
\end{tabular}

Terlihat nilai p pada fase induksi sebesar 0,672 dan nilai p pada fase konsolidasi yaitu 0,460. Hal ini menunjukkan bahwa $\mathrm{p}>0,05$.

Tabel 5. Perbedaan LFG pada fase induksi dan fase konsolidasi

\begin{tabular}{ccc}
\hline Fase Kemoterapi & $\begin{array}{c}\text { Selisih } \\
\text { rata-rata }\end{array}$ & $\begin{array}{c}\text { p-value } \\
\text { (nilai p) }\end{array}$ \\
\hline $\begin{array}{c}\text { Fase Induksi - } \\
\text { Fase Konsolidasi }\end{array}$ & $-3,1056$ & $0,660^{*}$ \\
\hline
\end{tabular}

Terjadi peningkatan laju filtrasi glomerulus yaitu sebanyak 3,1056 $\mathrm{ml} / \mathrm{mnt} / 1,73 \mathrm{~m}^{2}$. Namun peningkatan ini tidak bermakna karena nilai p pada hasil uji Wilcoxon didapatkan yaitu 0,660. Hal ini menunjukkan bahwa $\mathrm{p}>0,05$.

Tabel 6. Hubungan risiko LLA dengan stadium Acute Kidney Injury

\begin{tabular}{lcccc}
\hline & \multicolumn{4}{c}{ Stadium } \\
& \multicolumn{3}{c}{ Acut Kidney Injury } & \multirow{2}{*}{ Nilai p } \\
\cline { 2 - 4 } & Normal & Risk & Injury & \\
\hline Induksi & & & & \\
SR LLA & 15 & 1 & 1 & \\
HR LLA & 22 & 3 & 0 & 1,000 \\
Total & 37 & 4 & 1 & \\
Konsolidasi & & & & \\
SR LLA & 14 & 3 & 0 & \\
HR LLA & 24 & 0 & 1 & 0,992 \\
Total & 38 & 3 & 1 & \\
\hline
\end{tabular}

Dengan menggunakan metode Uji Kolmogorov Smirnov Z didapatkan niai $\mathrm{p}$ pada fase induksi yaitu 1,000 dan fase konsolidasi yaitu 0,992. Hal ini menunjukkan bahwa nilai $\mathrm{p}>0,05$.

\section{BAHASAN}

Pada penelitian yang dilakukan terlihat bahwa anak dengan LLA terbanyak pada kelompok usia 2-12 tahun yaitu sebanyak 36 kasus $(85,7 \%)$ dan terendah pada kelompok usia kurang dari 2 tahun, yaitu hanya sebanyak 2 kasus (4,8\%).

Kriteria usia pada penderita LLA dapat dikaitkan dengan prognosis dari penyakit LLA itu sendiri. Anak-anak penderita LLA yang berusia antara 2 tahun sampai 9 tahun (standard risk) mempunyai prognosis yang lebih baik dibandingkan dengan anak yang 
berusia kurang dari 1 tahun atau lebih dari 10 tahun yang menderita LLA (high risk). ${ }^{8}$

Dari hasil penelitian berdasarkan jenis kelamin, jumlah sampel laki-laki sama dengan jumlah sampel perempuan yaitu masing-masing berjumlah 21 kasus (50,0\%). Hasil ini berbeda dengan penelitian yang dilakukan oleh Meidiana di RSUP Dr. Cipto Mangunkusumo memperlihatkan bahwa jumlah pasien lakilaki lebih banyak daripada pasien perempuan, yaitu sebesar 65 dan 61 kasus LLA. $^{5}$ Penelitian yang dilakukan oleh Widiaskara $d k k$ juga memdapatkan hasil yang sama, yaitu jumlah sampel anak lakilaki penderita LLA lebih banyak daripada sampel anak perempuan penderita LLA.,5

Karakteristik sampel yang juga diteliti yaitu berdasarkan risiko LLA, dari hasil penelitian didapatkan bahwa sampel dengan high risk LLA lebih banyak ditemukan daripada standard risk LLA, dengan hasil 17 kasus (40,5\%) pada standard risk dan 25 kasus (59,5\%) pada high risk. Berbeda dengan penelitian yang dilakukan oleh Yetty bahwa jumlah sampel dengan standard risk lebih banyak daripada sampel high risk yaitu 71 dan 48 kasus.

Standard risk dan high risk merupakan gambaran dari prognosis LLA. Standard risk LLA memberikan prognosis yang lebih baik dibandingkan dengan high risk LLA. Adapun faktor-faktor yang dapat membedakan keduanya, yaitu usia penderita, jumlah leukosit awal, ada atau tidaknya penyakit pada sistem saraf pusat saat didiagnosis, dan respon terhadap terapi yang diberikan. ${ }^{8,9}$ Faktor utama yang berperan dalam memperburuk penyakit LLA adalah jumlah leukosit yang tinggi dalam darah, yaitu lebih dari $50.000 / \mathrm{mm}^{3}$. Kejadian morbiditas dan mortalitas lebih tinggi pada pasien dengan leukosit > 50.000/ul yang terjadi pada fase induksi kemoterapi, dan umumnya disebabkan karena sepsis dan perdarahan hebat. ${ }^{8}$

Hasil analisis perbandingan LFG pada high risk dan standard risk LLA, melalui perhitungan LFG menggunakan rumus Schwartz dengan mengambil nilai kadar kreatinin, menunjukkan bahwa tidak ada hubungan yang bermakna ( $\mathrm{p}>0,05)$ antara risiko LLA (high risk dan standard risk) dengan laju filtrasi glomerulus (LFG) pada fase induksi dan fase konsolidasi. Hasil ini berarti bahwa tinggi atau rendahnya laju filtrasi glomerulus pada fase induksi dan konsolidasi tidak dipengaruhi oleh risiko LLA.

Selain mengetahui perbandingan LFG antara high risk LLA dan standard risk LLA, peneliti melakukan analisis selisih rata-rata LFG untuk fase induksi terhadap fase konsolidasi dan didapatkan bahwa adanya peningkatan LFG yaitu sebanyak 3,1056 $\mathrm{ml} / \mathrm{mnt} / 1,73 \mathrm{~m}^{2}$. Namun peningkatan LFG pada fase induksi ke fase konsolidasi yang terjadi tidak ada perbedaan secara bermakna, sebab setelah dilakukan uji Wilcoxon untuk mengetahui perbedaan LFG antara fase induksi dan fase konsolidasi, didapatkan bahwa nilai p yaitu 0,660 . Hal ini berarti tidak ada perubahan yang bermakna pada laju filtasi glomerulus ketika berada di fase induksi maupun di fase konsolidasi.

Pada penelitian ini, peneliti juga melakukan analisis hubungan risiko LLA dengan stadium acute kidney injury. Hasil analisis menunjukkan bahwa tidak ada hubungan yang bermakna $(\mathrm{p}>0,05)$ antara standard risk dan high risk dengan stadium Acute Kidney Injury. Ini berarti tingkatan dari stadium Acute Kidney Injury tidak bisa diprediksi atau ditentukan hanya dengan mengacu pada risiko LLA yang dialami oleh pasien, baik risiko tinggi LLA (high risk) maupun risiko standar LLA (standard risk).

Kemoterapi merupakan pengobatan utama untuk pasien LLA, namun kemoterapi dapat mempengaruhi sel dan organ normal tubuh. Efek samping kemoterapi dibagi menjadi early side effect contohnya neutropenia dan stomatitis, serta delayed side effect. ${ }^{10,11}$ Metotreksat adalah obat anti-metabolit yang banyak digunakan dalam kemoterapi, efek samping yang dapat timbul akibat obat ini terutama apabila digunakan dalam dosis yang tinggi yaitu kerusakan mukosa ginjal, depresi sumsum tulang, sampai dengan terjadinya 
acute kidney injury. Selain metotreksat, vinkristin juga dapat mempengaruhi sistem saraf berupa hilangnya refleks tendon achilles, konstipasi, nyeri abdominal, dan gangguan fungsi hati. ${ }^{11,12}$

Sitarabin juga dapat menyebabkan efek samping berupa leukopenia, trombositopenia, dan gangguan fungsi hati. Oleh karena itu baik sebelum dilakukan kemoterapi, selama kemoterapi, dan sesudah kemoterapi dapat diberikan terapi suportif pada pasien LLA yaitu hidrasi cairan baik secara oral atau infus 2 - 3 $\mathrm{L} / \mathrm{m}^{2} /$ hari dan pemberian obat anti-emetik untuk mengurangi efek obat. Selain itu dapat diberikan juga asam folat seperti leucovorin untuk mengurangi efek samping obat khususnya untuk metotreksat. ${ }^{11,12}$

Komplikasi ginjal yang terjadi pada pasien LLA sering dihubungkan dengan beberapa faktor, yaitu infiltrasi sel leukemia ke dalam sel ginjal dan juga karena pengaruh dari pengobatan terhadap sel kanker itu sendiri. Komplikasi terhadap ginjal tersebut tidak jarang terjadi dan kebanyakan terjadi pada fase induksi, serta bisa bertahan sampai beberapa tahun atau bahkan mungkin bisa menjadi permanen. Komplikasi yang sering terjadi ialah pembesaran ginjal yang disebabkan oleh infiltrasi sel leukemia ke dalam sel ginjal. Selain pembesaran ginjal, acute kidney injury (gagal ginjal akut) juga merupakan salah satu komplikasi ginjal yang berat akibat penyakit LLA, walaupun masih jarang terjadi. ${ }^{7,12}$

Pada penelitian didapatkan hal yang sama bahwa kejadian acute kidney injury pada pasien LLA di RSUP Prof. Kandou Manado jarang didapatkan. Hal tersebut mungkin disebabkan oleh prosedur kemoterapi dan pemberian terapi suportif yang telah dilaksanakan dengan baik sehingga efek samping pada ginjal jarang terjadi. Pada acute kidney injury terjadi penurunan laju filtrasi glomerulus dan fungsi tubulus secara tiba-tiba, sehingga menyebabkan gangguan pengeluaran produk sisa metabolisme seperti kreatinin, urea, dan fosfat, akibatnya dapat menimbulkan azotemia dan gangguan homeostasis cairan tubuh. ${ }^{9}$

\section{SIMPULAN}

Berdasarkan hasil penelitian yang dilakukan di Pusat Pengobatan Kanker Bangsal Estella RSUP Prof. DR. R.D Kandou Manado, mengenai gambaran fungsi ginjal pada anak dengan terapi leukemia limfoblastik akut, dapat disimpulkan bahwa fungsi ginjal anak usia 2-12 tahun pada kelompok high risk (risiko tinggi) dan kelompok standard risk (risiko standar) setelah menjalani kemoterapi fase induksi dan fase konsolidasi tidak ada perbedaan yang signifikan.

\section{SARAN}

Berdasarkan hasil penelitian, penulis menyarankan agar berhati-hati dalam memberikan dosis obat kemoterapi kepada pasien anak. Selain itu, perlu juga dilakukan pemeriksaan fungsi ginjal sebelum kemoterapi, selama kemoterapi, dan sesudah kemoterapi pada fase induksi dan konsolidasi untuk anak kanker.

\section{UCAPAN TERIMA KASIH}

Ucapan terima kasih disampaikan kepada Prof. Dr. dr. Max Mantik, SpA(K) dan Dr. dr. Suryadi Tatura $\operatorname{SpA}(\mathrm{K})$ selaku dosen penguji skripsi. Juga kepada semua pihak baik yang secara langsung maupun tidak langsung telah menambahkan ide dan gagasan bagi penulis sehingga dapat menyelesaikan artikel ini.

\section{DAFTAR PUSTAKA}

1. Price SA, Wilson LM. Patofiologi. volume 1, edisi ke-6. Jakarta; penerbit Buku Kedokteran EGC, 2006.

2. Pinontoan E, Mantik M, Rampengan N. Pengaruh kemoterapi terhadap profil hematologi pada penderita leukemia limfoblastik akut. Sari pediatric.

3. Widiaskara $M$, Bambang $\mathbf{P}$, Mia $\mathbf{R}$. Luaran pengobatan fase induksi pasien leukemia limfoblastik akut pada anak di RSU Dr. Soetomo. Sari pediatik. 2010;12:1-7.

4. Wahab $S$, Behrman $R$, Kliegman $R$, Arvin A, editor. Nelson Ilmu kesehatan 
anak. Ed 15. Jakarta; penerbit Buku Kedokteran EGC, 2012.

5. Bangun M. Analisa faktor kejadian relaps pada anak dengan leukemia di RSUP DR. Cipto Mangunkusumo [tesis]. Jakarta: Universitas Indonesia; 2012.

6. Lukman A. Pemberian kemoterapi pada gagal ginjal. FK-USU Medan.2012:122.

7. Canadian Cancer Society. Kidney damage and chemotherapy. 2014 [diakses : 2014 November 10] Available from://http:// Kidney damage and chemotherapy - Canadian Cancer Society.html

8. Ariawati $\mathrm{K}$, Windiastuti $\mathrm{E}$, Gatot $\mathrm{D}$. Toksisitas kemoterapi leukemia limfoblastik akut pada fase induksi dan profilaksis susunan saraf pusat dengan metoreksat 1 gram. Sari pediatric. 2007;9:1-7.

9. Hoffbrand AV, Pettit JE, Moss PAH. Kapita Selekta Hematologi. Ed 4. Jakarta; penerbit Buku Kedokteran EGC, 2012.

10.Windiastuti E, Mulawi C. Gangguan metabolik pada leukemia limfobastik akut dengan hiperleukositosis. Sari pediatri. 2002;4:31-5.

11.Yulia T. Gambaran tingkat pengetahuan pasien tentang pengobatan kemoterapi di rumah sakit kanker dharmais [Skripsi]. Depok: Universitas Indonesia;2012.

12.Gunawan SG, Setiabudy $R$, Nafrialdi. Farmakologi dan terapi. Edisi ke-5. Jakarta; Fakultas Kedokteran Universitas Indonesia, 2011. 